IRA-International Journal of Education \& Multidisciplinary Studies

ISSN 2455-2526; Vol.08, Issue 01 (July 2017)

Pg. no. 130-141

Institute of Research Advances

http://research-advances.org/index.php/IJEMS

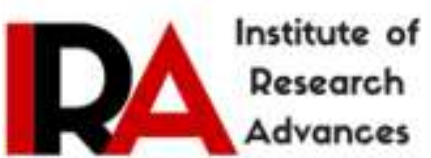

\title{
At Attention: What Student Veteran Mission Statements Say About Public Flagships
}

\author{
Zachary W Taylor \\ orcid.org/0000-0002-6085-2729 \\ The University of Texas at Austin, United States.
}

Type of Review: Peer Reviewed.

DOI: http://dx.doi.org/10.21013/jems.v8.n1.p13

How to cite this paper:

Taylor, Z.W. (2017). At Attention: What Student Veteran Mission Statements Say About Public Flagships. IRA International Journal of Education and Multidisciplinary Studies (ISSN 2455-2526), 8(1), 130-141. doi: http://dx.doi.org/10.21013/jems.v8.n1.p13

(c) Institute of Research Advances.

\section{(cc) EY-NC}

This work is licensed under a Creative Commons Attribution-Non Commercial 4.0 International License subject to proper citation to the publication source of the work.

Disclaimer: The scholarly papers as reviewed and published by the Institute of Research Advances (IRA) are the views and opinions of their respective authors and are not the views or opinions of the IRA. The IRA disclaims of any harm or loss caused due to the published content to any party.

Institute of Research Advances is an institutional publisher member of Publishers Inter Linking Association Inc. (PILA-CrossRef), USA. The institute is an institutional signatory to the Budapest Open Access Initiative, Hungary advocating the open access of scientific and scholarly knowledge. The Institute is a registered content provider under Open Access Initiative Protocol for Metadata Harvesting (OAI-PMH).

The journal is indexed \& included in WorldCat Discovery Service (USA), CrossRef Metadata Search (USA), WorldCat (USA), OCLC (USA), Open J-Gate (India), EZB (Germany) Scilit (Switzerland), Airiti (China), Bielefeld Academic Search Engine (BASE) of Bielefeld University, Germany, PKP Index of Simon Fraser University, Canada. 


\begin{abstract}
Expanding Wilson, Meyer, and McNeal's (2012) work focusing on university mission statements, this study further explicates the values expressed by public flagship institutions $(n=50)$ through the linguistic examination of student veteran services mission statements disseminated by student veterans services offices, representing a gap in the literature. A quantitative linguistic analysis reveals only $24 \%$ of student veteran services offices feature official mission statements on their websites, these mission statements do not support extant research or the U.S. Department of Education's guidelines for supporting student veterans, and mission statements do not directly address student veterans, evidenced by first- and third-person pronouns. Implications for student veteran support and adult learning are addressed.
\end{abstract}

Keywords: higher education, linguistics, mission statements, student veterans, military veterans

\title{
Introduction
}

According to the National Center for Education Statistics (2015), over 70\% of all 2011-2012 undergraduates could be considered nontraditional and adult learners, and of this group, student veterans are one of the fastest growing subpopulations of adult learners (Schiavone \& Gentry, 2014). This is largely due to 2009's post9/11 GI Bill, which greatly expanded higher education benefits to military service members and veterans: since then, hundreds of thousands of student veterans have used their GI Bill benefits and enrolled at institutions of higher education (IHEs) in the United States (Cate, 2014). As of 2011, 51.7\% of student veterans graduated in four-years compared to 59\% of younger, non-veteran peers (U.S. Department of Education, 2015). Coupling the growing numbers of student veterans with their postsecondary achievement gap, colleges and universities across the country have increased their student veteran services in recent years (Griffin \& Gilbert, 2015), yet many of these servicesand the subsequent literature - has focused on the mental health (Cleveland, Branscum, Bovbjerg \& Thorburn, 2015; Nyaronga \& Toma, 2015) and transitions between active duty and college enrollment (Elliott, Gonzalez, \& Larsen, 2011; Rumann \& Hamrick, 2010) instead of the guiding principles, mission, and vision of student veteran services offices at countless postsecondary institutions across the country. Before evaluating student veteran services, higher education research should first evaluate these guiding beliefs in order to better understand how and why student veteran services offices - and their mission statements - operate in the way they do: this study seeks to fill this gap in the literature.

Broadening the discussion of adult learning to encompass student veterans, this study seeks to answer two simple questions:

1.) Who is the audience of student veteran services mission statements?

2.) What core values are asserted by student veteran services mission statements?

Student veteran mission statements from each public flagship in the United States $(\mathrm{n}=50)$ are examined, employing word frequency and collocation linguistic analyses to determine the audience(s), core values, and priorities articulated by public flagship institutions in the United States as they relate to student veterans, an important and burgeoning subpopulation of adult learners.

\section{Literature Review}

\section{Significance of a Higher Education Mission Statement}

For decades, institutions of higher education - and their many departments, offices, divisions, and special programs - have drafted and published mission statements. Of institution-level mission statements, Masland (1985) argued that institutions produce publicly disseminated documents meant to convey a sense of an institution's curriculum, campus climate, and belief system: mission statements in particular are direct reflections of an institution's culture. Additionally, institutional mission statements are often written by a collective leadership aware of the complexity of a student's role within an institution, equating a student to a customer receiving a variety of educational services. As a result, institutions of higher education constantly assess and reassess the student's role within their institution to refine and redefine institutional strategies for maximizing resources to serve students based on the articulation of a mission statement (Conway, Mackay, \& Yorke, 1994). Given this flux, recent research on postsecondary mission statements found that such statements provide two chief institutional benefits: to help 
organizational members delineate between institutional and non-institutional activities and promote a shared, stable sense of purpose in order to inspire and motivate all organizational members to uphold and share that purpose with others. These benefits are especially pertinent to student veterans and the institutional services they receive at public institutions, as mission statements articulated by public institutions reflect, rather than drive, the realities of an institution, as compared to the mission statements of private institutions which are much more aspirational in nature (Morphew \& Hartley, 2006).

Furthermore, mission statements can also help leadership dictate how physical space and resources-such as student veteran services offices - are organized, allotted, and used by faculty, staff, and students, with different types of institutions articulating different mission statements depending on the types of students served, programs offered, and community service provided (Fugazzotto, 2009). This connection between an institution's mission statement and the specific population it serves is further evidenced by the conflict experienced by community colleges in composing aspirational mission statements instead of student-centered, realistic mission statements (Lake \& Mrozinski, 2011) and Albany State's student protest after the omission of its heritage as a historically-Black university in its new mission statement after its merger with Darton State College (Journal of Blacks in Higher Education, 2016).

Offices, departments, and divisions within an institution can also produce and promote their own mission statements, given the population it serves and the resources its allotted, such as the articulation of mission statements for diversity organizations (Wilson, Meyer, \& McNeal, 2012), academic libraries (Hardesty, Hastreiter, \& Henderson, 1988), faculty senates (D’Souza, Clower, Nimon, Oldmixon \& Van Tassell, 2011), intercollegiate athletics (Ward, Jr., 2015), and degree programs (Creamer \& Ghoston, 2013; Holosko, Winkel, Crandall, \& Briggs, 2013). However, the mission statements of student veteran services offices have been overlooked by the fields of adult learning and higher education. It seems appropriate to examine these mission statements to better inform practitioners to best practices and emerging trends to appropriately serve student veterans.

\section{Current Best Practices of Student Veteran Services Offices on College Campuses}

In 2013, the U.S. Department of Education, in cooperation with the departments of Veterans Affairs and Defense, drafted a list of "8 Keys for Veterans' Success" on college campuses, specifically outlining strategies for IHEs to support student veterans. The list is below:

1. Create a culture of trust and connectedness across the campus community to promote well-being and success for veterans.

2. Ensure consistent and sustained support from campus leadership.

3. Implement an early alert system to ensure all veterans receive academic, career, and financial advice before challenges become overwhelming.

4. Coordinate and centralize campus efforts for all veterans, together with the creation of a designated space for them (even if limited in size).

5. Collaborate with local communities and organizations, including government agencies, to align and coordinate various services for veterans.

6. Utilize a uniform set of data tools to collect and track information on veterans, including demographics, retention, and degree completion.

7. Provide comprehensive professional development for faculty and staff on issues and challenges unique to veterans.

8. Develop systems that ensure sustainability of effective practices for veterans.

As of 2016, the U.S. Department of Education had received commitments from 2,134 IHEs who agreed to uphold the eight keys for student veteran success on their respective campuses, yet the U.S. Department of Education makes clear on their website that, "a listing here is not a representation or assurance by the U.S. Department of Education that an institution has implemented the 8 Keys or how well it has implemented them, and it does not constitute an endorsement by the U.S. Department of Education of these institutions or their policies or programs" (U.S. Department of Education, 2016). As a result, many IHEs have committed to the eight keys, but there is no standard of measurement of said commitment for practitioners to engage with and reflect upon current practices. 
An accountability measure for postsecondary institutions and their support of student veterans was first proposed in 2014 - the Veterans Education Outcomes Act-by California Rep. Mark Takano, Bill Flores, and the Committee on Veterans' Affairs, which would have required IHEs to produce documentation that details completion rates, employment rates, and retention rates of individuals receiving GI Bill funding (H.R. 4248, 2014). In 2015, another related bill was not enacted by Congress - the Veteran Education Empowerment Act - which would have established a federal grant program to provide support to IHEs in establishing, maintaining, and improving veteran student centers on college campuses (H.R. 5589, 2015). Since, IHEs have only been informed by the latest version of the GI Bill (2008) which provided student veterans with enhanced educational benefits and the ability for beneficiaries to transfer their benefits to spouses or children: however, no U.S. government legislation has addressed the functions, purposes, and roles of student veteran offices on college campuses in delivering these benefits to student veterans.

\section{Practitioner Implementation of the "8 Keys"}

Considering this lack of direction and official government mandate, higher education researchers have provided foundational guidance to IHEs in the form of the analysis of evaluation of current student veteran services practices on college campuses, many mirroring the "8 Keys."

First, identifying student veterans and providing clear, well-organized communication with these individuals is of the utmost importance for practitioners working with student veterans. Creating a supportive, encouraging environment is critical, but actively communicating with student veterans and paying close attention to their circumstances, backgrounds, and support structures breeds success (Moon \& Schma, 2011; Romero, Riggs, \& Ruggero, 2015). As an outlet for social interaction and collaboration with peers, participation in student veteran organizations has been linked to a greater sense of belonging and purpose as well as higher levels of student engagement on campus (Summerlot, Green, \& Parker, 2009). Also, having an academic or campus advisor who is also a veteran can be of benefit to student veterans, as sharing a mutual knowledge of military life helps promote a sense of campus belonging and understanding (Parks, Walker, \& Smith, 2015).

Extant research supports the notion that student veterans require mental health, counseling, and transition services given the often-traumatic events of active duty (Blosnich, Kopacz, McCarten, \& Bossarte, 2015; Cleveland, Branscum, Bovbjerg, \& Thorburn, 2015): most IHEs already provide on-campus mental health and counseling services for student veterans, as mental health difficulties often leads to student attrition (Nyaronga \& Toma, 2015). Also contributing to student veteran attrition is the phenomenon of "stopping out," or taking time off from college temporarily with the intention of returning to finish a degree, often occurring when a student veteran is redeployed, yet some universities do not track student veterans' precise reasons for stopping out (Alschuler \& Yarab, 2016). A lack of social support and adequate transition services also contributes to student veteran attrition, as the facilitation of positive interaction with family and friends is negatively associated with PTSD and student veteran attrition (Elliott, 2014), prompting student veteran services offices to provide organizational structures for student veterans to enjoy symbiotic academic and familial lives.

Furthermore, student veterans often come from diverse backgrounds and subsequent postsecondary experiences: research posits that male veterans (Alfred, Hammer, \& Good, 2013), female veterans (DiRamio, Jarvis, Iverson, Seher, \& Anderson, 2015), first-generation and low SES student veterans (Wurster, Rinaldi, Woods, \& Liu, 2013), student veterans with disabilities (Parks \& Walker, 2015), and student veterans with diverse sexual orientations (Pelts \& Albright, 2015) all have different postsecondary experiences and require individualized support services from a diversified practitioner base. Undergirding research posits that student veterans benefit from social and academic programming that recognizes and works to de-stigmatize and correct the common faculty, staff, and student perspective that all student veterans represent a monolithic, homogenous group (Vaccaro, 2015). Related research supports this premise, asserting that student veterans feel acknowledged and better understood when the multilayered, intersectional experiences of diverse student veterans are discussed in public panel formats, allowing student veterans to share their idiosyncratic journeys from active duty to the college campus: this organizational responsibility rests with practitioners working with student veterans (Osborne, 2014).

However, no research exists examining student veteran services offices and their guiding mission statements to inform whether the " 8 Keys" or any extant research is being embraced and conveyed by these offices to prospective and current student veterans. If this research is performed, practitioners working with student veterans 
would be much better informed as to current best practices, emerging trends, and core belief systems espoused by other student veteran services offices across the country.

\section{Data}

Sample

First, a measure of standardization was required, since I expected varied student veteran services mission statements across state lines, levels of institutional resources, and institutional missions. I decided upon the examination of public flagship institutions given two chief statistics: nearly $70 \%$ of student veterans choose to attend public institutions (Radford, 2009), and public institutions are more likely to offer student veteran services (74\%) compared to private institutions (51\%) (McBain, Kim, Cook \& Snead, 2012). Therefore, the sample was limited to the fifty public flagship institutions of higher education as a means to concentrate on institutions which student veterans are most likely to attend and institutions most likely to provide services, thus making a large contribution to the current practitioner knowledge base. However, even this small decision was fraught with difficulty, as several states are considered to have two flagships (e.g., The University of Texas at Austin and Texas A\&M University) or do not have an official flagship institution (e.g., Idaho and Ohio). The institutions included in the sample can be provided upon request.

Second, recent research revealed that a college or university's website is the primary means by which a prospective student learns about a school before applying (Saichaie \& Morphew, 2014), and the vast majority of precollege students - both veterans and non-veterans - seek out pre-college information via the internet to supplement either phone or in-person queries about a particular institution (Burdett, 2013). For this reason, the examination of web-based student veteran services mission statements seemed appropriate, as a veteran participating in the "search" period of the college selection process (Hossler \& Gallagher, 1987) would likely use the internet to inquire about student veteran services at a given institution before applying and enrolling.

Furthermore, not every public flagship institution included an official student veteran services mission statement delineated as such on their website. This means that it is possible that certain student veteran mission statements were omitted from this study on the basis that they were not specifically demarcated as "mission statements" on the institution's website or were not included on the institution's website. As a result, for a student veteran services mission statement to be included in this study, the mission statement needed to be clearly demarcated and identified as such on the institution's website.

\section{Data Collection}

Student veteran mission statements were collected in November 2016 following the search protocol articulated by Wilson, Meyer, and McNeal (2012). To locate each student veteran services mission statement, I narrowed the focus of the data collection by using each institution's domain-embedded search tool, instead of a general internet search using a common search engine (e.g., Google, Yahoo, Bing). Then, I used the institutional tool to search for the following terms: "veterans," "student veterans," "student veteran services," and "student veteran services mission statement." If this search did not yield a student veteran services mission statement, I searched each institution's website to learn if the institution had a dedicated office, department, or division for student veterans by searching for "veteran office" in the institution's domain-embedded search tool. Searches averaged between 20 and 30 minutes to locate each student veteran services mission statement, if one was included on the institution's website.

\section{Data Analysis}

Once the student veteran services mission statement was located, its text was extracted and uploaded into a Microsoft Excel database. Word frequency and collocation analyses were calculated by Readability Studio linguistic analysis suite by uploading the database into the program and then sorting the data by word frequency and collocation pairs of most frequently used words in each statement. I sorted the data by Student Affairs Professionals in Higher Education (NASPA) region for two reasons. First, extant research demonstrates that student veterans express different social and academic needs in different geographic regions of the United States (DiRamio, Ackerman, \& Mitchell, 2008). Second, as a practitioner-focused study, I mean to maximize the generalizability of the sample size by sorting the text data in a regionally-balanced and representative fashion. Once again, I limited the number of frequently used words and collocated pairs in each NASPA region corpus and the overall corpus given the relatively small but appropriate sample size. 


\section{Delimitations}

This study is chiefly limited to student veteran services mission statements of public flagship institutions in the United States: conclusions cannot be drawn about private, for-profit, community college, or other institution types. Furthermore, textual analysis was limited to the student veteran services mission statements alone, yet institutions can express their beliefs and attitudes toward student veterans through other forms of media (e.g., promotional videos, marketing materials, and social media): these media were not included in the data collection. Finally, aforementioned in the previous section of this paper, student veteran services mission statements were extracted from institution websites in November 2016: it is possible that institutions could have uploaded new or altered existing statements since then. However, these limitations represent areas of further research and analysis.

\section{Findings}

Word Frequency Analysis of Student Veteran Mission Statements

A word frequency and collocation analysis of student veteran services mission statements can be found in the Tables $[1,2,3]$ given below:

\section{Table 1}

List of Public Flagship Universities

\begin{tabular}{|c|c|c|c|}
\hline$\underline{\text { State }}$ & Institution & State (cont'd) & Institution \\
\hline Alabama & U of Alabama, Tuscaloosa & Montana & U of Montana \\
\hline Alaska & U of Alaska, Fairbanks & Nebraska & U of Nebraska, Lincoln \\
\hline Arizona & $\mathrm{U}$ of Arizona & Nevada & U of Nevada, Las Vegas \\
\hline Arkansas & U of Arkansas & New Hampshire & U of New Hampshire \\
\hline California & U of California, Berkeley & New Jersey & Rutgers \\
\hline Colorado & U of Colorado, Boulder & New Mexico & UNM, Albuquerque \\
\hline Connecticut & $\mathrm{U}$ of Connecticut & New York & SUNY, Buffalo \\
\hline Delaware & U of Delaware & North Carolina & UNC, Chapel Hill \\
\hline Florida & U of Florida & North Dakota & U of North Dakota \\
\hline Georgia & U of Georgia & Ohio & Ohio State U \\
\hline Hawaii & U of Hawaii, Manoa & Oklahoma & $\mathrm{U}$ of Oklahoma \\
\hline Idaho & U of Idaho & Oregon & U of Oregon \\
\hline Illinois & U of Illinois, Urbana-Champaign & Pennsylvania & Pennsylvania State U \\
\hline Indiana & IU Bloomington & Rhode Island & U of Rhode Island \\
\hline Iowa & $\mathrm{U}$ of Iowa & South Carolina & USC, Columbia \\
\hline Kansas & U of Kansas & South Dakota & U of South Dakota \\
\hline Kentucky & U of Kentucky & Tennessee & U of Tennessee, Knoxville \\
\hline Louisiana & Louisiana State U & Texas & $\mathrm{U}$ of Texas, Austin \\
\hline Maine & U of Maine, Orono & Utah & U of Utah \\
\hline Maryland & U of Maryland, College Park & Vermont & $\mathrm{U}$ of Vermont \\
\hline Massachusetts & U of Massachusetts, Amherst & Virginia & U of Virginia \\
\hline Michigan & U of Michigan, Ann Arbor & Washington & U of Washington, Seattle \\
\hline Minnesota & U of Minnesota, Twin Cities & West Virginia & West Virginia U \\
\hline
\end{tabular}




$\begin{array}{llll}\text { Mississippi } & \text { U of Miss, Oxford } & \text { Wisconsin } & \text { U of Wisconsin, Madison } \\ \text { Missouri } & \text { U of Missouri, Columbia } & \text { Wyoming } & \text { U of Wyoming }\end{array}$

Table 2

Word Frequency Analysis of Student Veteran Services Office Titles

\begin{tabular}{|c|c|c|}
\hline NASPA & \# of & \\
\hline$\underline{\underline{\text { Region }}}$ & $\underline{\text { Institutions }}$ & $\underline{5 \text { Most Frequent Words }}$ \\
\hline 1 & 6 & $\begin{array}{l}\mathrm{t} 1 * \text { : services }(4), \mathrm{t} 2: \text { veteran }(3), \mathrm{t} 3: \text { veterans }(3) \mathrm{t} 4: \text { affairs, military }(2) \mathrm{t} 5: \text { six different } \\
\text { terms }(1)\end{array}$ \\
\hline 2 & 6 & $\begin{array}{l}\mathrm{t} 1 \text { : office }(3), \mathrm{t} 2 \text { : veteran }(3), \mathrm{t} 3 \text { : programs, services, veterans }(2), \mathrm{t} 4 \text { : six different terms } \\
(1)\end{array}$ \\
\hline 3 & 10 & $\mathrm{t} 1:$ services $(6), \mathrm{t} 2$ : veterans $(6), \mathrm{t} 3$ : student $(5), \mathrm{t} 4$ : veteran $(4), \mathrm{t} 5$ : military $(3)$ \\
\hline
\end{tabular}

\begin{tabular}{|c|c|c|}
\hline $4 \mathrm{~W}$ & 10 & $\begin{array}{l}\mathrm{t} 1 \text { : veteran, center }(6), \mathrm{t} 2 \text { : student }(5), \mathrm{t} 3 \text { : veteran }(4), \mathrm{t} 4: \text { services, resource }(3), \mathrm{t} 5 \text { : ten } \\
\text { different terms }(1)\end{array}$ \\
\hline 5 & 7 & $\begin{array}{l}\mathrm{t} 1: \text { veteran (4), t2: office, center (3), t3:veterans, student, services (2), t4: six different } \\
\text { terms (1) }\end{array}$ \\
\hline 6 & 3 & $\mathrm{t} 1$ :veterans $(3), \mathrm{t} 2$ : seven different terms (1) \\
\hline
\end{tabular}

10 Most Frequent Words

$\mathrm{t} 1$ : veterans (25), t2: services (25), t3: veteran (23), t4: student (17), t5: center (13)

t6: office (12), t7: military (10), t8: resource (5), t9: affairs (4), support (4), t10:

Corpus $50 \quad$ assistance, programs (3)

$* \mathrm{t}=$ term 1 is most frequent, $\mathrm{t} 5$ is fifth most frequent

Table 3

Word Frequency and Collocation Analysis of Student Veteran Services Mission Statements

\begin{tabular}{lll}
$\frac{\text { NASPA }}{\frac{\text { Region }}{\text { and \# of }}}$ & & \# of \\
$\underline{\text { Ins. }}$ & $\underline{\text { Statements }}$ & $\underline{3 \text { Most Frequent Words and Collocated Pairs }}$ \\
$1(6)$ & 0 & n/a \\
& $\begin{array}{l}\text { t1: military (7), t2: college, our, veteran, veterans, their (4), t3: university, transition, } \\
\text { services, programs, life (3) } \\
\text { cp1*: "student" and "veterans" (2); "military" and "programs" (2); "college" and "life" (2) }\end{array}$ \\
\hline $3(6)$ & 3 &
\end{tabular}


$\mathrm{t} 1$ : veterans (3), t2: services, student, their, mission (2), t3: 10+ different terms (1)

cp1: "student" and "veterans" (2); "provide" and "services" (2)

t1: student (3), t2: support, services (2), t3: $10+$ different terms (1)
4E (7) 11 cp1: "student" and "support" (2); "support" and "services" (2)

(10) 2 cp1: "student" and "veterans" (3), cp2: "veterans" and "academic" (2)

t1: student (11), t2: veterans, their (10), t3: veteran, service, community (7)

cp1: "student" and "veterans" (4), cp2: "student" and "veteran" (3), cp3: "their" and

5 (7) $3 \quad$ "sacrifices" (2)

$\mathrm{t} 1$ : veteran (3), t2: facilitate (2), t3: 10+ different terms (1)

$6(3) \quad 1 \quad$ cp1: "veteran" and "services" (2); "facilitate" and "veteran" (2)

$\mathrm{t} 1$ : veterans (24), t2: student (21), t3: their (18), t4: veteran (16), t5: our, military (12)t6: services (11)

t7: service, community (9), t8: support, life (8), t9: university, we (7), t10: mission, academic (6)

Corpus cp1: "veterans" and "student" (20), cp2: "veteran" and "student" (19), cp3: “our" and (50) $12 \quad$ "student" (12)

$*_{\mathrm{cp}}=$ collocated pair 1 is the pair of two most frequently collocated words, collocated pair 3 is the two least frequently collocated words

\section{Discussion}

After reviewing the findings, a number of themes emerge. To begin, the lack of clearly-demarcated student veteran services mission statements is troublesome: only 12 institutions, representing $24 \%$ of the sample, featured student veteran services mission statements on their institutional websites. Given the importance of how an institutional mission statement articulates the goals, priorities, and resources of a given institution (Conway, Mackay, \& Yorke, 1994; Fugazzotto, 2009; Morphew \& Hartley, 2006), student veteran services offices need to better communicate their purposes and functions to their prospective and current student veteran population.

Regarding audience, it is clear that student veteran services mission statements do not address prospective student veterans. By frequently using the first-person possessive pronoun "our" and third-person possessive pronoun "their," these mission statements effectively address student veterans who are already enrolled in the institution (e.g., "our veterans" and "their needs") instead of prospective student veterans. Supporting this finding is the lack of use of the second-person pronoun "you," which is used to directly address a reader, or in this case, a prospective student veteran hoping to learn more about a student veteran services office and their goals, priorities, and support services. As a result, it is clear that student veteran services mission statements are not written to address prospective student veterans.

An absence of "academics," "finances," and "careers" in mission statements contradicts extant research and the U.S. Department of Education's "8 Keys" as being important for student veteran success. In fact, the " 8 Keys" explicitly asserts that student veteran services offices should "ensure all veterans receive academic, career, and financial advice" (Key 3) which directly impacts "retention and degree completion" (Key 6). Extant research has already established that institutions do not adequately track student veterans' reasons for "stopping out," (Alschuler \& Yarab, 2016), yet it seems that student veteran services offices do not address the "academic," "financial," or "career" concerns and needs of student veterans, and if they do, they do not make these support services clear in their mission statement.

Next, given that a chief concern of student veteran researchers and student veterans themselves is the mental health of this population, the insufficiency of clearly articulated mental health and transition services offered by student veteran services offices is worthy of further consideration. Extant research has overwhelmingly established 
the fact that student veterans require individualized mental health and transition services to ensure success on a college campus (Blosnich, Kopacz, McCarten, \& Bossarte, 2015; Cleveland, Branscum, Bovbjerg, \& Thorburn, 2015), yet student veteran services mission statements simply do not address this need. It is entirely possible that such offices do not directly provide mental health and transition services for student veterans - perhaps another office or department on campus provides this support-yet a prospective or current student veteran may not understand this nuance or understand that such support services are available outside of an official student veteran services office. If decentralizing of student veteran services is indeed being practiced on college campuses across the country, operating in such a way is in direct conflict with Key 4 of the U.S. Department of Education's "8 Keys": "Coordinate and centralize campus efforts for all veterans." In no uncertain terms, high quality, individualized mental health and transition services are crucial for student veteran success. Given the lack of linguistic attention to these issues in mission statements, student veteran services offices across the country do not make these services mental health and transition services clear in both location and description.

Finally, acknowledging the fundamental lack of understanding of student veteran diversity on college campuses (Vaccaro, 2015), institutional student veteran services mission statements do not address the notion of student veteran diversity and the subsequent idiosyncratic support services this diversity requires. In fact, no mission statements frequently used the word "diversity," rendering these mission statements - and by proxy, these campuses - potentially uninviting for diverse student veterans and adult learners.

\section{Implications for Practitioners Working With Student Veterans}

Given that extant research and the US Department of Education's "8 Keys," student veteran services offices - and their mission statements—-should reflect these emerging sources of best practices. First, all student veteran services offices should consult extant research to carefully compose and then publish official mission statements on their websites: student veterans deserve this sense of institutional transparency and support. Furthermore, student veteran services offices should consult extant research and adapt their mission statements to best convey the student services offered by such offices. Also, student veteran services offices and their mission statements should make clear that a physical space exists on campus and that student veteran services are offered at that physical space: extant research and the US Department of Education's "8 Keys" support this notion.

Moreover, student veteran services mission statements should be as detailed as possible and be written to address both future and prospective student veterans from diverse backgrounds. Student veteran services mission statements should reflect this attention to audience, as well as be inclusive of all types of student veterans and their idiosyncratic personal and professional backgrounds. Campuses across the country have drafted and published official diversity mission statements (Wilson, Meyer, \& McNeal, 2012): student veteran services offices should follow suit.

Perhaps this study's most salient implication for practitioners is the nature of veterans' college choice. The Internet is the most popular source of pre-college information for students across populations (Burdett, 2013), and student veterans in particular base their college choice on cost and convenience (Dunklin, 2012; Field 2008; Sander, 2012). If student veteran offices and their mission statements do not clearly articulate the beliefs, goals, and purposes of student veteran services offices - particularly paying attention to financial and convenience servicesthese offices may be deterring or ignoring a large population of adult learners who have earned the right to exercise their GI Bill benefits and enroll in the institution that best serves their needs.

Ultimately, student veteran services offices serve an incredible population of adult learners. However, these offices need to stand "at attention" and pay as much attention as possible to the current body of research to truly best serve those who have served our country.

\section{References}

[1] Alfred, G. C., Hammer, J. H., \& Good, G. E. (2013). Male student veterans: Hardiness, psychological wellbeing, and masculine norms. Psychology of Men \& Masculinity, 15(1), 9599.http://psycnet.apa.org/doi/10.1037/a0031450

[2] Alschuler, M., \& Yarab, J. (2016). Preventing student veteran attrition: What more can we do? Journal of College Student Retention: Research, Theory, and Practice, 1-20. http://dx.doi.org/10.1177/1521025116646382 
[3] Blosnich, J. R., Kopacz, M. S., McCarten, J., \& Bossarte, R. M. (2015). Mental health and self-directed violence among student service members/veterans in postsecondary education. Journal of American College Health, 63(7), 418-426.http://dx.doi.org/10.1080/07448481.2014.931282

[4] Burdett, K. (2013). How students choose a college: Understanding the role of internet based resources in the college choice process (Doctoral dissertation, University of Nebraska at Lincoln, Lincoln, NE). Retrieved from:

a. http://digitalcommons.unl.edu/cgi/viewcontent.cgi? article=1158\&context=cehsedaddiss

[5] Cate, C. A. (2014). Million records project: Research from Student Veterans of America. Retrieved from https://studentveterans.org/images/Reingold_Materials/mrp/download-materials/mrp_Full_report.pdf

[6] Cleveland, S. D., Branscum, A. J., Bovbjerg, V. E., \& Thorburn, S. (2015). Mental health symptoms among student service members/Veterans and Civilian College Students. Journal of American College Health, 63(7), 459-472. http://dx.doi.org/10.1080/07448481.2014.983925

[7] Conway, T., Mackay, S., \& Yorke, D. (1994). Strategic planning in higher education: Who are the customers? International Journal of Educational Management, 8(6), 29-36.https://doi.org/10.1108/09513549410069202

[8] Creamer, E. G., \& Ghoston, M. (2013). Using a mixed methods content analysis to analyze mission statements from colleges of engineering. Journal of Mixed Methods Research, 7(2), 110120.http://dx.doi.org/10.1177\%2F1558689812458976

[9] DiRamio, D., Ackerman, R., \& Mitchell, R. L. (2008). From combat to campus:. NASPA Journal, 45(1), 73-102. http://dx.doi.org/10.2202/1949-6605.1908

[10] DiRamio, D., Jarvis, K., Iverson, S., Seher, C., \& Anderson, R. (2015). Out from the shadows: Female student veterans and help-seeking. College Student Journal, 49(1), 49-68. Retrieved from http://www.ingentaconnect.com/content/prin/csj/2015/00000049/00000001/art00007

[11] D’Souza, D. E., Clower, T. L., Nimon, K. F., Oldmixon, E. A., \& Van Tassell, F. S. (2011). Developing a mission statement for a faculty senate. Planning for Higher Education, 39(2), 15-24. Retrieved from http://search.proquest.com/openview/59de2799b20c6db706b8fb374e1bfe2a/1 ?pq-origsite=gscholar\&cbl=47536

[12] Dunklin, S. B. (2012). The transfer veteran student experience: Exploring college choice, transition, and collegiate experiences of veterans (Doctoral dissertation). Retrieved from DigitalCommons database.

[13] Elliott, M. (2015). Predicting problems on campus: An analysis of college student veterans. Analyses of Social Issues and Public Policy, 15(1), 105-126. http://dx.doi.org/10.1111/asap.12066

[14] Elliott, M., Gonzalez, C., \& Larsen, B. (2011). US military veterans transition to college: Combat, PTSD, and alienation on campus. Journal of Student Affairs Research and Practice, 48(3), 279296.http://dx.doi.org/10.2202/1949-6605.6293

[15] Field, F. (2008, July 25). Cost, convenience drive veterans' college choice. Retrieved from http://www.chronicle.com/article/Cost-Convenience-Drive/20381

[16] Fugazzotto, S. J. (2009). Mission statements, physical space, and strategy in higher education. Innovative Higher Education, 34(285).http://dx.doi.org/10.1007/s10755-009-9118-z

[17] Griffin, K. A., \& Gilbert, C. K. (2015). Better transitions for troops: An application of Schlossberg's transition framework to analyses of barriers and institutional support structures for student veterans. The Journal of Higher Education, 86(1), 71-97. https://doi.org/10.1353/jhe.2015.0004

[18] Hardesty, L., Hastreiter, J., \& Henderson, D. (1988). Development of college library mission statements. Journal of Library Administration, 9(3), 11-34.http://dx.doi.org/10.1300/J111v09n03_03

[19] Holosko, M. J., Winkel, M., Crandall, C., \& Briggs, H. (2015). A content analysis of mission statements of our top 50 schools of social work. Journal of Social Work Education, 51(2), 222236.http://dx.doi.org/10.1080/10437797.2015.1012922

[20] Hossler, D., \& Gallagher, K. S. (1987). Studying student college choice: A three-phase model and the implications for policymakers. College and University, 62(3), 202-221. Retrieved from ERIC database. (Accession No. EJ354226)

[21] The Journal of Blacks in Higher Education. (2016, March 18). Albany State students protest the adoption of the university's new mission statement. Retrieved from

https://www.jbhe.com/2016/03/albany-state-students-protest-the-adoption-of-the-universitys-new-missionstatement/ 
[22] Lake, R. S., \& Mrozinski, M. D. (2011). The conflicted realities of community college mission statements. Planning for Higher Education, 39(2), 5-14. Retrieved from http://search.proquest.com/openview/786d9f49de0d361a1facaca2c3f3f4d6/1?pq-origsite=gscholar\&cbl=47536

[23] Masland, A. T. (1985). Organizational culture in the study of higher education. The Review of Higher Education, 8(2), 157-168.https://doi.org/10.1353/rhe.1985.0026

[24] McBain, L., Kim, Y. M., Cook, B. J., \& Snead, K. M. (2012, July). From soldier to student II: Assessing campus programs for veterans and service members. Retrieved fromhttp://www.acenet.edu/newsroom/Documents/From-Soldier-to-Student-II-Assessing-Campus-Programs.pdf

[25] Moon, T. L., \& Schma, G. A. (2011). A proactive approach to serving military and veteran students. New Directions for Higher Education, 2011(153), 53-60.https://doi.org/10.1002/he.426

[26] Morphew, C. C., \& Hartley, M. (2006). Mission statements: A thematic analysis of rhetoric across institutional type. The Journal of Higher Education, 77(3), 456-471. Retreived from www.jstor.org/stable/3838697

[27] Nyaronga, D., \& Toma, R. (2015). Student service members/veterans' mental health: Who is at a greater risk for posttraumatic stress symptoms on college campuses? Military Psychology, 27(4), 223231.http://dx.doi.org/10.1037/mil0000079

[28] Osborne, N. J. (2014). Student veteran discussion panels: Deconstructing the traumatized veteran stigma on campus. About Campus, 19(2), 24-29. https://doi.org/10.1002/abc.21153

[29] Parks, R., \& Walker, E. (2014). Understanding student veteran disabilities. College \& University, 90(1), 53-74. Retrieved from http://search.proquest.com/openview/95be70508d61662f3594ba8f42353d58/1?pqorigsite $=$ gscholar $\& \mathrm{cbl}=1059$

[30] Parks, R., Walker, E., \& Smith, C. (2015). Exploring the challenges of academic advising for student veterans. $\begin{array}{lllll}\text { College } \quad \& \quad \text { University, } & 90(4), & 37-52 . & \text { Retrieved }\end{array}$ http://search.proquest.com/openview/2287613fb558ef1b123d2bc7d6c8fce4/1?pq-origsite=gscholar\&cbl=1059

[31] Pelts, M. D., \& Albright, D. L. (2015). An Exploratory Study of Student Service Members/Veterans' Mental Health Characteristics by Sexual Orientation. Journal of American College Health, 63(7), 508512.http://dx.doi.org/10.1080/07448481.2014.947992

[32] Pickens, M. L. (2013). An exploration of factors affecting retention and persistence of undergraduate military veteran students at the University of Missouri (Doctoral dissertation). Retrieved from ProQuest database. (Accession No. 10157293)

[33] Radford, A. W. (2011, September). Stats in Brief: Vol. NCES 2011-163. Military service members and veterans. Retrieved from http://nces.ed.gov/pubs2011/2011163.pdf

[34] Romero, D. H., Riggs, S. A., \& Ruggero, C. (2015). Coping, family social support, and psychological symptoms among student veterans. Journal of Counseling Psychology, 62(2), 242-252. http://psycnet.apa.org/doi/10.1037/cou0000061

[35] Rumann, C. B., \& Hamrick, F. A. (2010). Student veterans in transition: Re-enrolling after war zone deployments. The Journal of Higher Education, 81(4), 431-458. Retrieved from www.jstor.org/stable/40835661

[36] Saichaie, K., \& Morphew, C. C. (2014). What college and university websites reveal about the purposes of higher education. The Journal of Higher Education, 85(4), 499-530.https://doi.org/10.1353/jhe.2014.0024

[37] Sander, L. (2012, April 27). With GI Bill's billions at stake, colleges compete to lure veterans. Retrieved from http://www.chronicle.com/article/With-GI-Bills-Billions-at/131723

[38] Schiavone, V., \& Gentry, D. (2014). Veteran-students in transition at a midwestern university. Journal of Continuing Higher Education, 62(1), 29-38. http://dx.doi.org/10.1080/07377363.2014.872007

[39] Summerlot, J., Green, S.-M., \& Parker, D. (2009). Student veterans organizations. New Directions for Student Services, 2009(126), 71-79. https://doi.org/10.1002/ss.318

[40] US Department of Education. (2015, September). Demographic and enrollment characteristics of nontraditional undergraduates: 2011-12 (Publication No. NCES 2015-025). Retrieved from http://nces.ed.gov/pubs2015/2015025.pdf

[41] US Department of Education. (2016). 8 keys to veterans' success. Retrieved from

a. http://www.ed.gov/veterans-and-military-families/8-keys-success-sites

[42] Vaccaro, A. (2015). It's not one size fits all: Diversity among student veterans. Journal of Student Affairs Research and Practice, 52(4), 347-358.http://dx.doi.org/10.1080/19496591.2015.1067224 
[43] Veteran Education Empowerment Act, H.R. 1399, 114th, 1st Sess. (2015).

[44] Veterans Education Outcomes Act, H.R. 4248, 113th, 2d Sess. (2014).

[45] Ward, Jr., R. E. (2015). Buried accomplishments: Institutional isomorphism in college athletics mission statements. International Journal of Sport Communication, 8(1), 18-28.https://doi.org/10.1123/IJSC.2014-0018

[46] Williams, D. N. (2015). Boots on the ground: Examining transition factors for military and veteran student academic success (Doctoral dissertation). Retrieved from ProQuest database. (Accession No. 3711967)

[47] Wilson, J. L., Meyer, K. A., \& McNeal, L. (2012). Mission and diversity statements: What they do and do not say. Innovative Higher Education, 37(2), 125-139. https://doi.org/10.1007/s10755-011-9194-8

[48] Wurster, K. G., Rinaldi, A. P., Woods, T. S., \& Liu, W. M. (2013). First-generation student veterans: Implications of poverty for psychotherapy. Journal of Clinical Psychology, 69(2), 127-137. https://doi.org/10.1002/jclp.21952 